\title{
Review
}

\section{Arendt, Levinas, and a politics of relationality}

\author{
Anya Topolski \\ Rowman \& Littlefield, London, New York, 2015, xix+265 pp., \\ ISBN: 978-1783483419
}

Contemporary Political Theory (2018) 17, S111-S114. https://doi.org/10.1057/s41296017-0137-8; published online 18 July 2017

The works of Emmanuel Levinas and Hannah Arendt guide Judith Butler's book on Jewishness and the critique of Zionism, Parting Ways (2012). Although Butler shares some topics, concerns, and interlocutors with the book under review here, Topolski is the first to engage in a systematic comparison of Arendt's and Levinas's work. Topolski 'stages a discussion' (p. xiii) between Arendt's political philosophy and Levinas's ethics in order to develop a 'political ethics,' more particularly a 'politics of relationality.' This is meant to 'awaken societies from their political slumber' (p. xii), that is, to combat democratic deficits and, in her view, widespread lack of interest in democracy in Western societies. As such, her argument fits in with the so-called 'ethical turn' in democratic theory, although she does not engage this debate directly.

Topolski's juxtaposition, confrontation, and 'rapprochement' of Arendt's conceptualization of plurality as the 'condition of the political' and Levinas's notion of alterity as 'the condition of the ethical' ( $\mathrm{p}$. xvi) may be controversial to many Arendt and Levinas scholars. However, she is cautious not to ethicize Arendt or to politicize Levinas, that is, to turn them into something they are not.

The book is divided in four parts, each consisting of two chapters. Part I sets the stage for the discussion by investigating the 'intersections' between Arendt's and Levinas's biographies and philosophies. Part II and Part III deal with Arendt's political (II) and Levinas's ethical philosophy (III), each part starting with a chapter exploring the key notions of plurality (Chapter 3) and alterity (Chapter 5), followed by a chapter on Arendt's ethics (Chapter 4) and Levinas's politics (Chapter 6). Finally, in Part IV, Topolski outlines her own project of a politics of relationality, which takes its bearings from both Arendt and Levinas while seeking to overcome their respective shortcomings.

Topolski draws four parallels between the two philosophical projects: the phenomenological approach; the influence of Heidegger; the attempt to come to terms, philosophically, with the Shoah; and the significance of the Jewish - or

(C) 2017 Macmillan Publishers Ltd. 1470-8914 Contemporary Political Theory Vol. 17, S3, S111-S114 
rather, Judaic - legacy in the development of Arendt's and Levinas's thought. Both born in Eastern Europe in 1906 and of Jewish descent, they became students of Heidegger, about whom each in her/his own way, grew ever more critical, not just regarding Heidegger's politics, but also his philosophical project, though neither of them ever abandoned this inspiration entirely. Both Levinas and Arendt adopted an unorthodox phenomenological approach, retroactively labeled the 'third generation' of phenomenology (the first generation referring to Husserl's, the second to Heidegger's work), alongside other, mostly French, politically or ethically engaged philosophers.

Topolski demonstrates that both Arendt's and Levinas's deconstructions of metaphysics - through the development of the notions of plurality and alterity, respectively, - are to be seen as responses to the Shoah, anti-Semitism, and totalitarianism. Still, their engagement with Jewish issues does not stop here, Topolski argues: it amounts to a more fundamental embedding in 'the Judaic.' If I understand Topolski well, she uses this neologism to refer to a particular 'cultural heritage' with a universalistic outlook, which is rooted in ancient rabbinic traditions, and, although inspired by the Torah, is not to be assimilated to this particular religion, Judaism (pp. 21-23). This definition allows one, she argues, to include the thought of non-practicing, secular Jews (such as Arendt) in the Judaic horizon.

Topolski also points out the tensions between Arendt's and Levinas's projects, tensions that might be obstacles for a dialogue: the 'disciplinary divide' between politics (or 'the political' as Topolski prefers to call it) and ethics. This obstacle is less insurmountable than it may seem, she argues, because it is possible to construct an Arendtian post-foundational ethics that speaks to Levinas's alterity, and a Levinasian critique of hierarchical politics that comes close to Arendt. Finally, Topolski predicates her 'politics of relationality' on the principles of Judaic hope (a faith in humanity, and a commitment to keep believing 'often against all odds'), of responsibility (a self-assigned responsibility for the Other that exceeds the discourse of rights, for example, through the practice of mitzvahs, good deeds) and, finally, of relationality, which provides an antidote to the collective condition of loneliness.

Whereas Topolski's account of Arendt's and Levinas's phenomenological, Heideggerian, and historical background is convincing, I have doubts about their shared Judaic inspiration. No reader of Levinas would deny the pivotal role of 'the Judaic' in his work, yet the same does not apply to Arendt. The latter was not even very familiar with the Judaic tradition, as Topolski indeed acknowledges (mainly in footnotes). Arendt's struggles with the meaning of Jewish identity and the way it played out in her public intellectual work receives surprisingly little attention. Her secular upbringing is not explored, and neither are the many public controversies over her (lack of) identification as a Jew: on several occasions, Arendt was charged with 'Jewish self-hatred' or even anti-Semitism, while Gershom Scholem blamed her for a lack of Ahabath Israel, love of the Jewish people, to mention but a few examples. And yet, despite her being a secular thinker who felt uneasy about 
religion (p. 10), Arendt was culturally deeply influenced by the Christian tradition, took a degree in theology, wrote her dissertation on Augustine's concept of caritas, and her work contains frequent references to the New Testament. For example, the principle of hope - one of the key elements of Topolski's politics of relationality is for her embodied in the birth of Jesus. More generally, Topolski's rendering of the notion of 'the Judaic' does not take account of the 'ethnic' and political dimensions of Jewishness. Arendt considered Jewishness both as a 'given' or 'natural facticity,' and as a socially attributed collective identity, which, under particular historical circumstances might present one with a political task, for 'if one is attacked as a Jew, one must defend oneself as a Jew. Not as a German, not as an upholder of the Rights of Man, or whatever. But: What can I specifically do as a Jew?' as she said in a 1964 interview. She was deeply ambivalent about Zionism, renouncing the modern European-style nationalism of its orthodox version, yet embracing its unorthodox rendering of the 'conscious pariah,' Bernard Lazare. Folding the 'natural' and political (Zionist as well as messianic) dimensions of Jewishness, and the tensions between them, into the notion of the Judaic would make it more fruitful for thinking about democratic politics. It would confront head-on its ineluctable element of struggle and contestation, of which the IsraelPalestine conflict is just one contemporary example.

This doubt ties in with my second concern. As much as I find Topolski's exploration of the relation between alterity and plurality conceptually sophisticated and original, I feel the promise of the politics of relationality - to bring a new perspective to contemporary debates on democracy - remains largely unfulfilled. Many ills of contemporary liberal democracies are mentioned - the refugee crisis, neoliberalism, the Israel-Palestine conflict - but none of them is addressed in depth to show the relevance of the relational ethos. The last part makes a case for a postfoundational ethics 'from within the political,' yet it does not follow the agonistic pluralism of most post-foundational democratic theorists. Though drawing on Oliver Marchart's influential book Post-foundational Political Thought/Die politische Differenz (2007/2010), Topolski does not engage with the promises (or pitfalls) of what Marchart calls the 'left Heideggerianism' of such thinkers as Nancy, Laclau, and Lefort. Topolski discusses the merits of her approach in the context of the somewhat obsolete debate between liberals, communitarians, and republicans instead of the much more relevant contemporary agonism-deliberation debate.

It is hard not to sympathize with the principles that inspire Topolski's ethos of relationality such as respecting difference. Yet in the public realm, difference - be it conceived as alterity or plurality - always implies conflict, struggle, and unequal power relations. As Ella Myers argues in her book Worldly Ethics. Democratic Politics and Care for the World (2013), the Levinasian ethos of responsibility provides a charitable model of ethics, which is ultimately depoliticizing and undemocratic, due to its inability to translate the relationship between ethical responsibility for the concrete other - the 'face-to-face,' as Topolski calls it - into

(C) 2017 Macmillan Publishers Ltd. 1470-8914 Contemporary Political Theory Vol. 17, S3, S111-S114 S113 
political responsibility in a plural world of many others with conflicting values, identities, and needs. Likewise, the therapeutic political ethos of care for the soul, which seems to accompany Topolski's Levinasian care for the other - her call for 'dealing with our own alterity' (p. 205) to counter the violence of 'allergic reactions' to the other - fails to make clear how working on the self can motivate collective democratic projects. Instead, Myers turns to Arendt to develop an ethos of amor mundi, care for the world, rather than care for the other/Other or the self, as a more promising democratic alternative. Still, the Arendtian ethos of care for the world also remains silent on the issue of unequal power relations.

Nevertheless, I found Topolski's discussion of hope as a democratic principle (Chapter 7) promising: the belief 'against all odds' that 'another world is possible' can be a source of inspiration for collective democratic struggles.

Marieke Borren

Utrecht University, Utrecht, The Netherlands

Open University, Heerlen, The Netherlands marieke.borren@ou.nl 